\title{
Anthropogenic and impact spherules: Morphological similarity and chemical distinction - A case study from India and its implications
}

\author{
Ambalika Niyogi ${ }^{1}$, Jayanta K Pati ${ }^{1, *}$, Suresh C Patel ${ }^{2}$, \\ DIPAK PANDA ${ }^{3}$ and SHIV K PATIL ${ }^{4}$ \\ ${ }^{1}$ Department of Earth and Planetary Sciences, University of Allahabad, Allahabad 211 002, India. \\ ${ }^{2}$ Department of Earth Sciences, Indian Institute of Technology, Powai, Mumbai 400 076, India. \\ ${ }^{3}$ EPMA Laboratory (PLANEX), Physical Research Laboratory, Thaltej Campus, Ahmedabad 380 009, India. \\ ${ }^{4}$ Dr. K.S. Krishnan Geomagnetic Research Laboratory, Leelapur Road, Hanumanganj, Allahabad 221 505, India. \\ *Corresponding author.e-mail: jkpati@yahoo.co.in
}

This paper provides first report of silica-rich anthropogenic spherules of varying colour, shape, size, surface texture and chemical composition found in road-deposited sediments (RDS) of Allahabad city, Uttar Pradesh, India. Morphological details and lithophile elemental composition of the silica-rich spherules are compared to microtektites and impact spherules from India to demonstrate their striking morphological similarities and chemical variability. This study suggests the need to use spherule data carefully while assigning an impact origin to spherule-finds or spherule-bearing lithological horizons.

\section{Introduction}

The evidences of oldest impact event on Earth due to the collision of large extraterrestrial objects come from Archean spherule layers exposed in South Africa and Australia ( 3.5-2.5 Ga; Glikson 2005; Simonson et al 2009 and references therein). The recent report about the catastrophic spread of coal fly ash spherules along with other particulate matter from the Lake Buchanan section, Sverdrup Basin, Canadian High Arctic (Grasby et al 2011) is believed to be related to/associated with the latest Permian extinction (LPE). However, spherules are formed in several ways in nature (Simonson et al 2009; French and Koeberl 2010; Saragnese et al 2010; Weiss et al 2010; Yang et al 2010). They can be of terrestrial (biogenic, industrial, diagenetic and volcanic), extraterrestrial (Fredriksson 1956) and they may also form due to the impacts of crater-producing meteorites (Raukas 2000; Osawa et al 2003; Kofman et al 2010). Early work on cosmic spherules was done by Fredriksson (1956) and it was shown that spherules as ablation products of meteorites as they pass through the Earth's atmosphere leading to the melting of interplanetary dust particles in the upper atmosphere as they get heated above their liquidus due to atmospheric friction. The anthropogenic source of spherules can be varied. This includes the combustion of fossil fuel (e.g., in diesel engines) contributes to the formation of spherules and their aggregates (Kim et al 2009). In addition, anthropogenic spherules can also originate from industrial and/or domestic heating systems (Goddu et al 2004; Gautam et al 2005). Coal combustion due to volcanic activity, thermal power plants and steam generation units

Keywords. Spherule; road dust; meteoritic impact; microtektites; fly ash. 
gives rise to significant emission of particulate matter and pollutants (Dayal and Sinha 2005; Sharma et al 2005; Bhanarkar et al 2008; Grasby et al 2011; http://elements.geoscienceworld.org/content/vol6/ issue4/\#ARTICLES). Unless evidence for meteorite impact is demonstrated, it is nearly impossible to differentiate between anthropogenic spherules, microtektites and impact spherules based on their morphology and/or geochemistry alone (Marini 2003; Buchner et al 2009; French and Koeberl 2010). However, the detection of shock metamorphic effects in mineral grains such as quartz or zircon as constituents of spherule layers provides unequivocal evidence for impact, as in the case of the $\mathrm{K} / \mathrm{Pg}$ boundary layer related to the $\sim 66 \mathrm{Ma}$ Chicxulub impact on the Yucatán peninsula, Mexico (e.g., Bohor 1990; Schulte et al 2010), the distal ejecta layer in the United Kingdom derived from the $\sim 215 \mathrm{Ma}$ Manicouagan impact structure, Québec, Canada (Walkden et al 2002) or worldwide-distributed Upper Eocene impact ejecta in connection with the $\sim 35$ Ma Popigai impact in Siberia (Montanari and Koeberl 2000; Whitehead et al 2000). Nevertheless, some putative impact ejecta layers still lack convincing evidence of shock metamorphic features, such as the spherules of the Barberton Greenstone Belt in South Africa earlier attributed to impact (Hofmann et al 2006).

As a result, in some instances anthropogenic spherules have been misidentified as microtektites (Marini 2003). At times magnetic properties of spherules have been used to decipher their extraterrestrial origin, whereas many consider them as contaminated terrestrial objects (Buchner et al 2009). A large database exists on the morphology and geochemistry of impact-generated spherules including tektites but similar data on anthropogenic spherules is semi-quantitative and scarce (Blaha et al 2008). In India, microtektites have been reported from the Indian Ocean sea floor based on their morphology (Prasad and Sudhakar 1998; Pattan et al 2010) and recently a study has been undertaken on the impact spherules from the basalt-hosted Lonar structure, India (Misra et al 2009) to understand the projectile chemistry. In case of Ramgarh structure, the morphological similarity and chemistry of 'spherules' have also been cited as impact diagnostic criteria (Sisodia et al 2006) although this

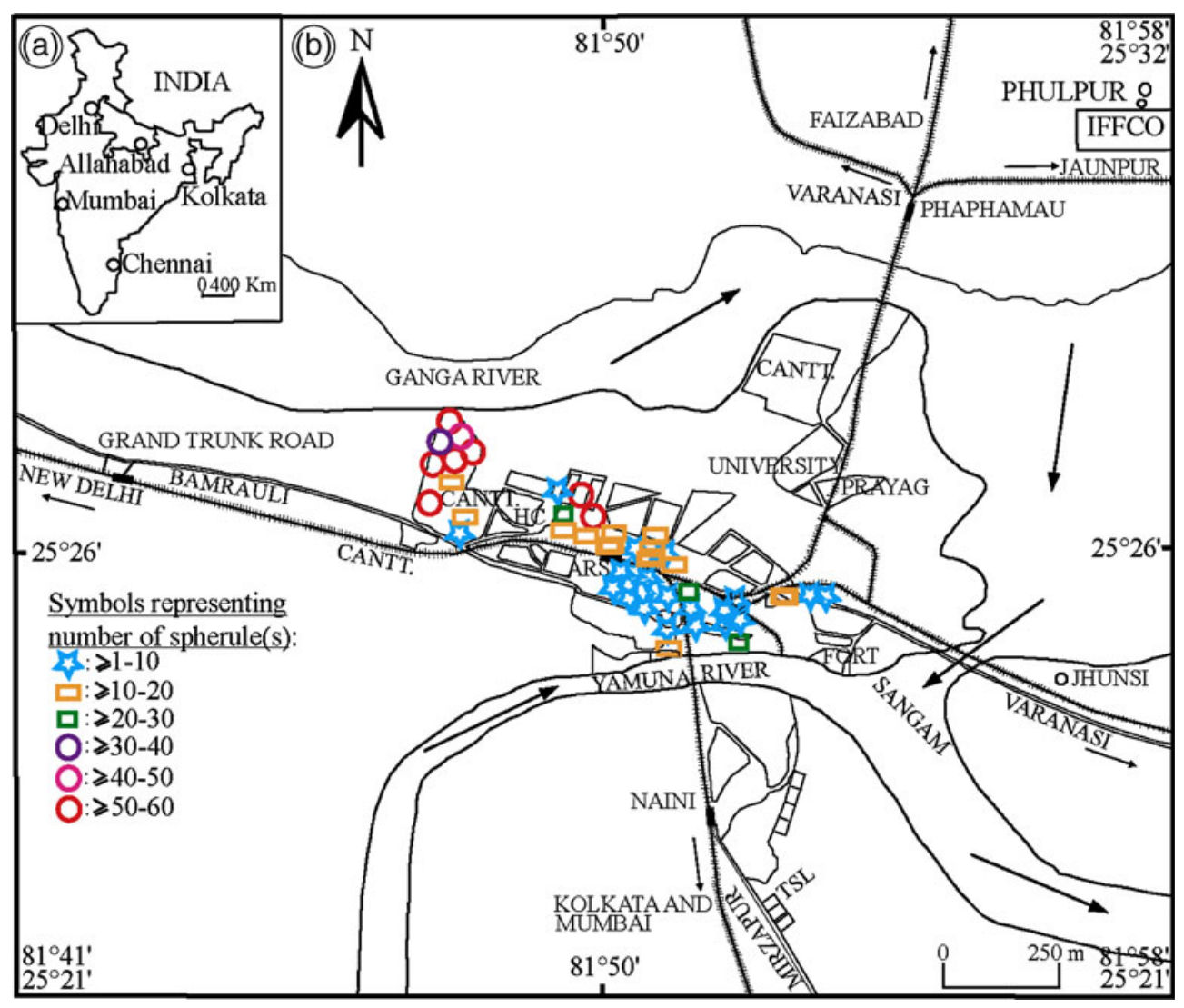

Figure 1. (a) The inset map of India showing the state of Uttar Pradesh and Allahabad city. (b) The traffic network map of Allahabad city with sample locations and number of spherules recovered per location shown with different symbols: Allahabad Railway Station (ARS), Cantonment (CANTT), High Court (HC). 
claim has been refuted later (Reimold et al 2006). However, the spherical shape of spherules is neither an indicator of impact cratering nor of melting (French and Koeberl 2010).

The present study provided the first report of silica-rich spherules (SS) from road-deposited sediments (RDS; after Thorpe and Harrison 2008) of Allahabad city, U.P., India (figure 1) of anthropogenic origin having excellent morphological similarity with impact-related spherules and microtektites known from the Indian subcontinent. This work also reports the chemical composition of anthropogenic glass spherules from Allahabad area for the first time and compares them with published data on microtektites from the Indian Ocean sea floor and spherules from the Lonar structure to establish their respective similarity and differences in terms of morphology, size, shape, colour and chemistry. This is intented to carefully evaluate the growing number of reports of probable/possible impact craters, microtektites and impact spherules from the Indian subcontinent mainly based on spherule morphology and chemistry.

\section{Materials and methodology}

The present study is focused on spherules observed in the RDS of Allahabad city. The road dust samples (200 gm each) were collected from 150 locations in plastic bottles during the months of April and May, 2009 covering the Allahabad city limits $\left(25^{\circ} 27^{\prime} 33.40^{\prime \prime}-25^{\circ} 26^{\prime} 33.40^{\prime \prime} \mathrm{N}\right.$ and $81^{\circ} 52^{\prime} 45.47^{\prime \prime}$ $81^{\circ} 52^{\prime} 33.40^{\prime \prime} \mathrm{E}$ ) and parts of the two satellite industrial townships, viz., Naini and Phulpur (figure 1) covering nearly $150 \mathrm{~km}^{2}$ area. Only 50 samples were included in the present study. Ten samples of SS were selected from different locations for analyses of lithophile elements by Electron Probe Micro-Analyser (Cameca SX-100) at the Physical Research Laboratory, Ahmedabad. The spherules were mounted with Araldite ${ }^{\circledR}$ on a conducting metallic stub of $2.5 \mathrm{~cm}$ diameter and coated with either gold or carbon. The electron microprobe analyses of spherules were performed on polished thin sections. The analyses were carried out at $10-15 \mathrm{kV}$ accelerating voltage, $25 \mathrm{~mA}$ beam current and 1-10 $\mu \mathrm{m}$ beam diameter. Both natural and synthetic standards were used for calibration. The detection limit was between 0.1 and $0.5 \mathrm{wt} \%$ depending on the element. SEM and BSE (Backscattered Electron) images were acquired to observe surface texture and chemical zonation, respectively. For every spherule at least five analyses were made at different spots. The number of spherules obtained from the representative samples of RDS range from 1 to 60 with an average of 18 spherules per location showing the spatial variability in their number (figure 1). The RDS collected from different locations across Allahabad city, in general, contain/comprise angular to sub-rounded clasts of quartz and feldspar, flakes of mica, gypsum flakes, lumps of cow dung, bones, broken glass, sugar cane husks, seeds, plastic and metallic fragments and spherules (both metallic and silicarich). The spherules are glassy in nature, which has been verified on the basis of standard petrographic techniques and X-ray diffraction study. This study is primarily confined to characterize the SS in the RDS identified in meso- to microscopic scale observations. About $10 \mathrm{gm}$ of samples were air-dried and used for microscopic observation and separation of different constituents. The samples were divided into two grain size fractions using a 35 mesh/500 $\mu \mathrm{m}$ sieve (ASTM; American Society for Testing Materials). Spherules were handpicked under a Leica stereozoom microscope. The abundance of spherules is less than 1 vol\% of RDS samples. The locations of 50 samples, number of spherules observed in each sample and morphology and colour of spherules are summarized in table 1 .

\section{Shapes and surface features of the spherules}

The specific properties of spherule shape have been used as an important criterion to identify spherules of impact origin (Simonson 2003) and shapes of impact spherules may vary from more angular to typically spherical types (Simonson et al 2000). Although spherical shapes of melt particles are the most common (aerodynamically-shaped) type observed, certain spherule shapes (teardrops and dumbbells) can be very common to a particular impact structure (e.g., Chicxulub, Mexico; Smit et al 1992). Sometimes the nonspherical shapes (ovoid, elongated, teardrop and dumbbell) are considered to have developed due to the breakup and spin of melt droplets as they get transformed from melt to glass (Simonson 2003). Agglutinated shapes have formed due to collision of molten spherules in flight but the exact processes giving rise to various external shapes of spherules is not fully answered (Simonson 2003). The microtektites reported from Indian Ocean are mostly spherical, however dumbbell shapes are also observed (Prasad and Sudhakar 1996) and 'impact spherules' from Lonar structure include shapes like spheres, teardrop, cylinders, dumbbells and spindles (Misra et al 2009). In addition, cratered and pitted surfaces of microtektites have been attributed to their impact origin (Prasad and Sudhakar 1996; Margolis et al 1971). 


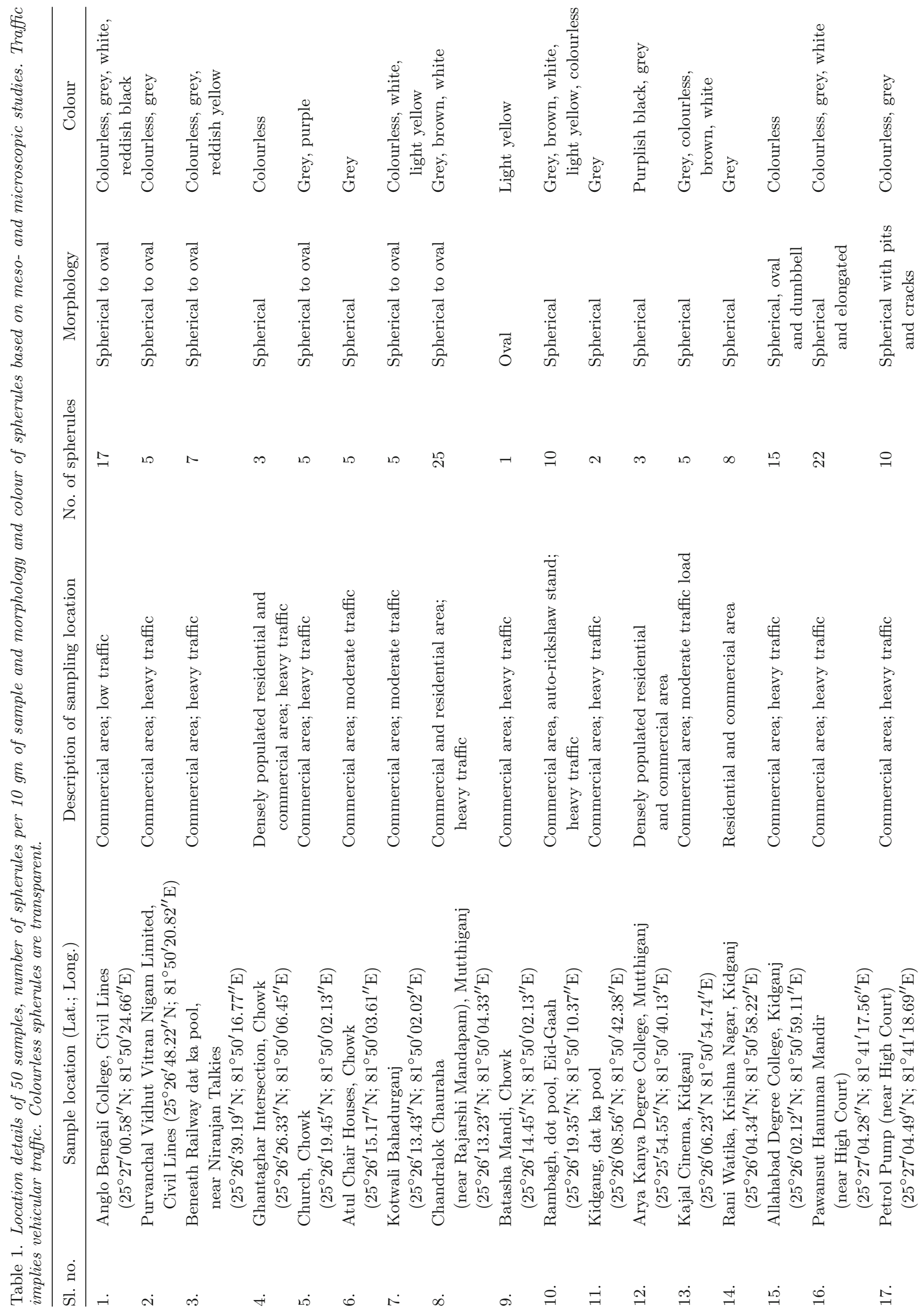




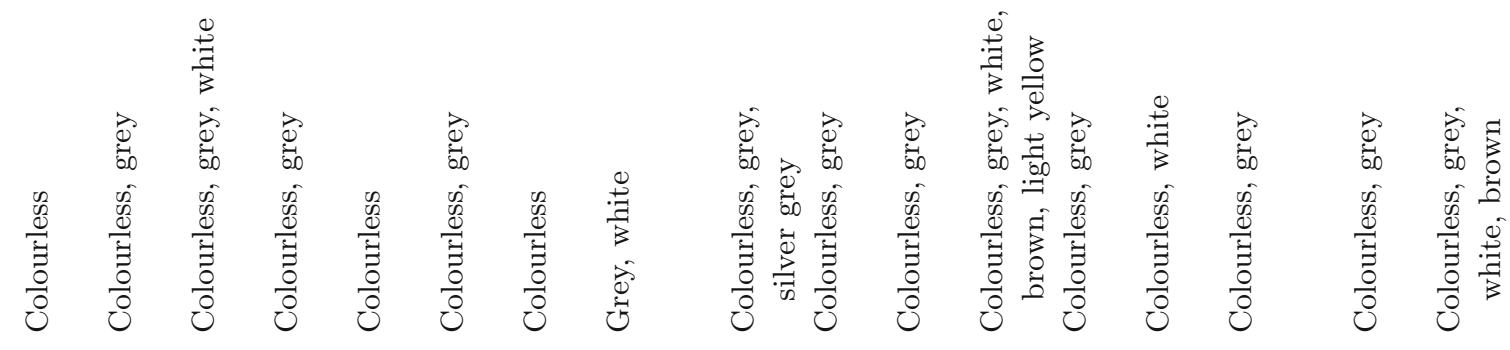

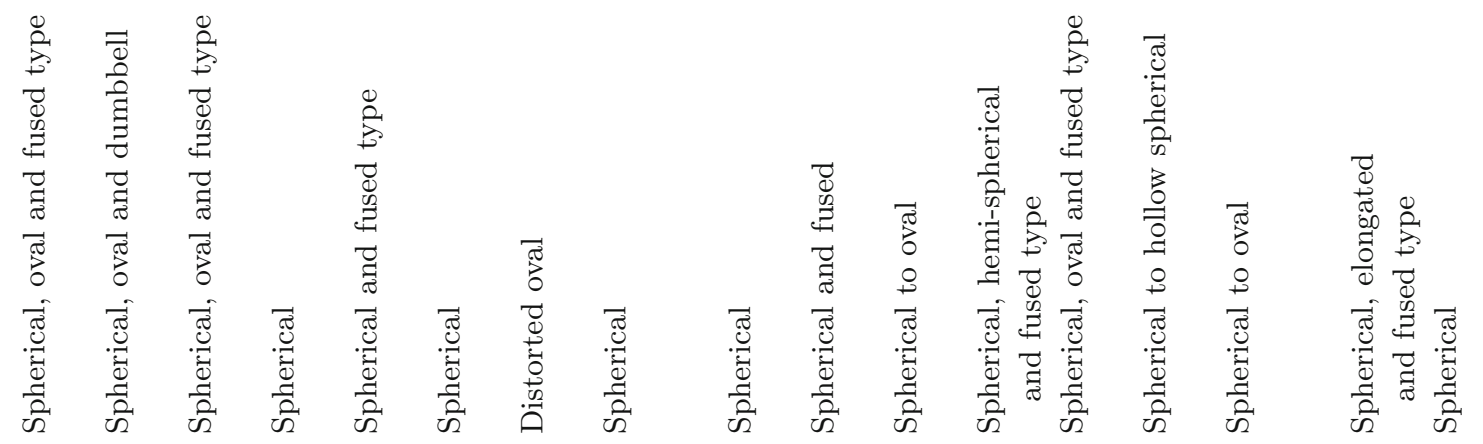

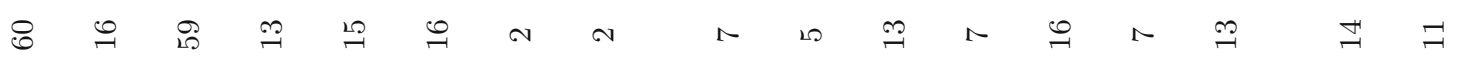

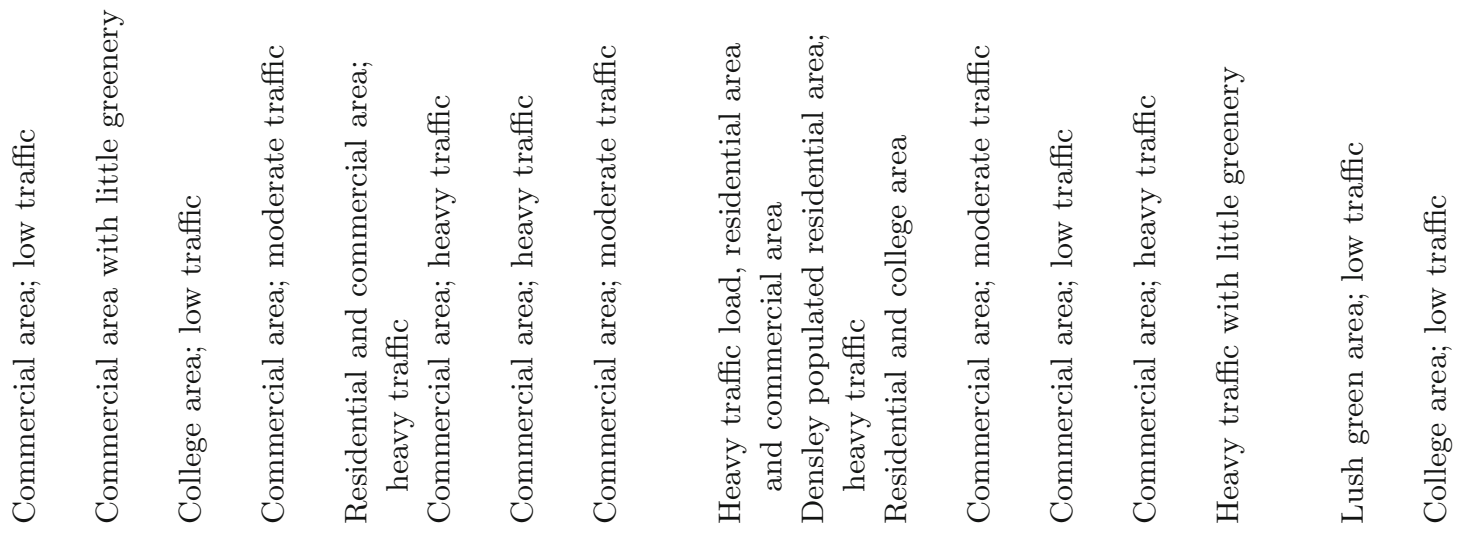

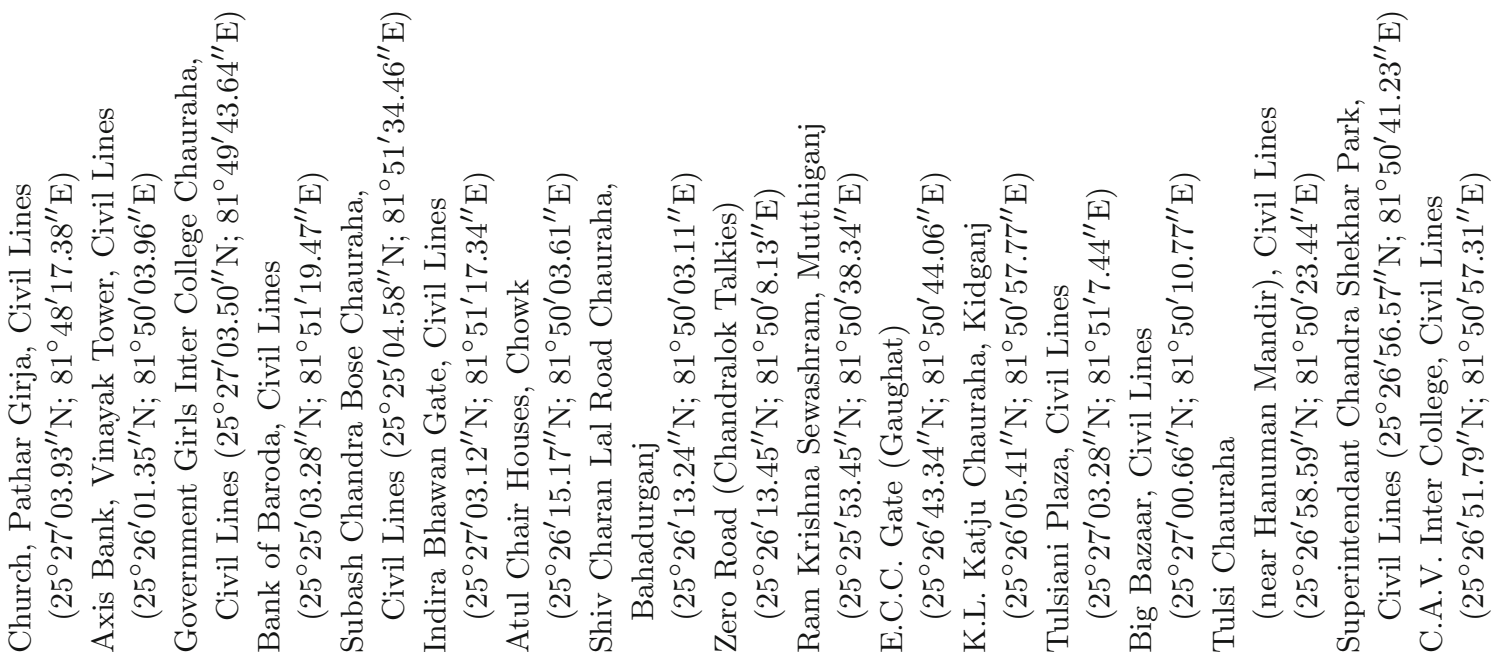

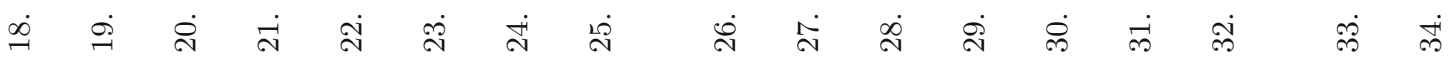




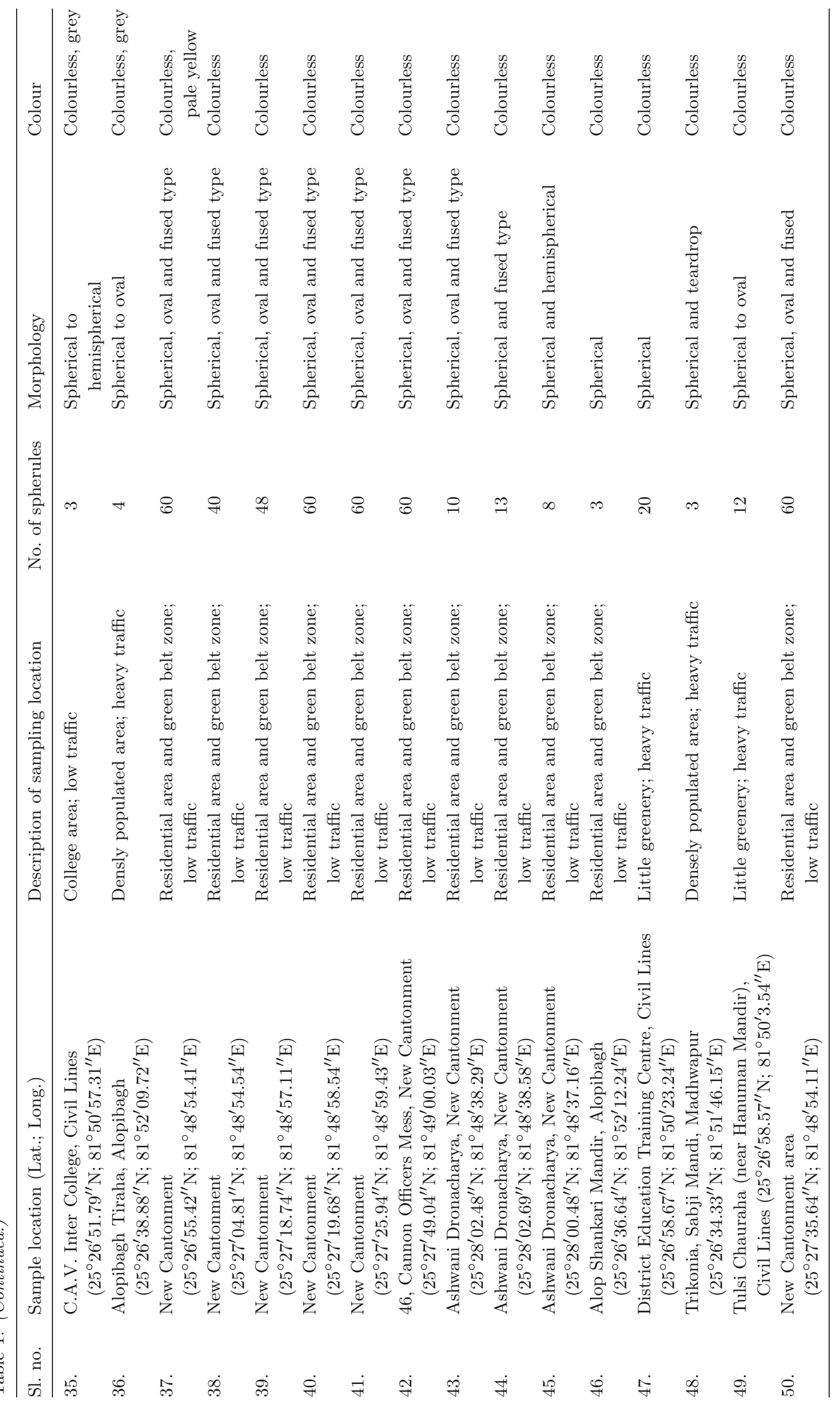




\section{Spherule sizes and their spatial distribution}

The size range of most Archean to Palaeoproterozoic impact spherules is constrained between 60 and $2000 \mu \mathrm{m}$, although some can measure up to 15$20 \mathrm{~mm}$ across (Simonson 2003). The spherules from Lonar crater (Misra et al 2009) are sub-millimeter $(0.3-1 \mathrm{~mm})$ to centimeter-sized (up to $\approx 30 \mathrm{~cm}$ ) and the microtektites from Indian Ocean range in size between 110 and $980 \mu \mathrm{m}$. The spherules can travel several hundreds of $\mathrm{km}$ suspended in air from various sources. In case of impact structures, their spatial distribution is divided into proximal and distal ejectas. Australasian tektites strewn field are known to spread over $>1$ million $\mathrm{km}^{2}$ area (Glass and $\mathrm{Wu}$ 1993).

\section{Colour variation in spherules and their occurrences}

The colour of the anthropogenic spherules (present study) varies from colourless (transparent) to grey, opaque white, brown, yellow and dark grey. The presence of colourless (transparent) spherules is dominated in the city while dark grey ones are observed in the southern part, i.e., industrial area, Naini of the city. On the contrary, the impact spherules are mostly coloured (orange, greenish, amber, brownish and dark grey; Weiss et al 2010) and microtektites are yellowish, yellowish white, white, greenish yellow and green in colour (Pattan et al 2010). The anthropogenic spherules are generally colourless as their silica content is very high and near absence of transition metal elements.

\section{Chemistry of the spherules}

In the absence of diagnostic evidence, the origin of spherules has always been a matter of debate. However, the geochemical analysis of spherules and/or spherule layers in a number of cases (based on PGEs abundances and relevant isotopic concentrations) has helped to resolve the problem pertaining to their origin (Lowe et al 1989; Kyte et al 2003; Simonson et al 2009). Since the projectile composition is not always chondritic, PGEs concentration too has limitations. Similarly microtektites also show wide chemical variation (basaltic to nearly pure silica in composition). The composition of anthropogenic spherules also depends on the chemistry of raw material(s) and at times practically impossible to distinguish them from spherules of impact origin. The nature of particulate pollutants can be predicted from the study of fly ash from the coal-based industrial heating systems (Jordanova et al 2006). The particles mainly comprise elements like, $\mathrm{Si}, \mathrm{Al}, \mathrm{S}, \mathrm{Ca}$, and Fe since raw coal is known to constitute kaolinite, quartz, siderite, calcite, pyrite, gypsum and sulphur (Xie et al 2009 and references therein). Many features, characteristic of Indian fly ash, are considerably different from the corresponding features of fly ash generated elsewhere (Sarkara et al 2005). However, there is currently no comprehensive dataset on the systematic geochemistry of anthropogenic spherules in the literature.

\section{Results and discussion}

The present study is based on the detailed analysis of 167 spherules from 50 representative sample sites. The shapes of the silica spherules from Allahabad RDS are mostly spherical to ovoid. The specific shapes observed include elliptical, dumbbell, cylindrical, tear-drop and spindle (figure $2 \mathrm{a}-\mathrm{e}$ ). Nearly $84 \%$ of the spherules are spherical and $16 \%$ of the spherules show the agglutinated form (adherence and coalescence features). Most or all of these aggregates tends to have appeared from the crystallization of the original melts (e.g., Scally and Simonson 2005; Sweeney and Simonson 2008) (figure 2f). The surface textures of anthropogenic spherules generally vary from smooth to pitted types having majority of irregular pits with some circular and jagged ones showing their resemblance to that of impact spherules. About 10-50\% of the surface area of the bigger (200-1000 $\mu \mathrm{m})$ spherules show pitted appearance ('cratered surface') whereas the smaller ones are relatively smooth (figure $2 \mathrm{~g}, \mathrm{~h}$ ). However, ring-like features reported by Prasad and Sudhakar (1998) around the pits in Indian Ocean microtektites have not been observed in silica spherules from the Allahabad RDS. The presence of bubbles and multiple bubble trails inside SS is occasionally noted.

The spherules present in Allahabad RDS measure from 100 to $200 \mu \mathrm{m}$ in size (in the case of 35 mesh-sized sieved dusts). However, in the unsieved samples, the size varies between > 200 and $1000 \mu \mathrm{m}$. The spherules in the size range of 100 $200 \mu \mathrm{m}$ are predominantly present in the vicinity of main industrial area (Naini; figure 1) and are mainly grey to dark grey in colour whereas the colourless spherules (>200 up to $1000 \mu \mathrm{m}$ ) can be seen both in residential and industrial areas of the city (figure 2a, b). The anthropogenic spherules observed in different parts of the Allahabad city exhibit a size range between 0.55 and $1.67 \mathrm{~mm}$ (figure 3). The size of the spherules shows a polymodal distribution with maximum number of spherules lying between 0.8 and $1 \mathrm{~mm}$ and their size range is similar to impact spherules (table 2). The silicate glass spherules are most abundant in 

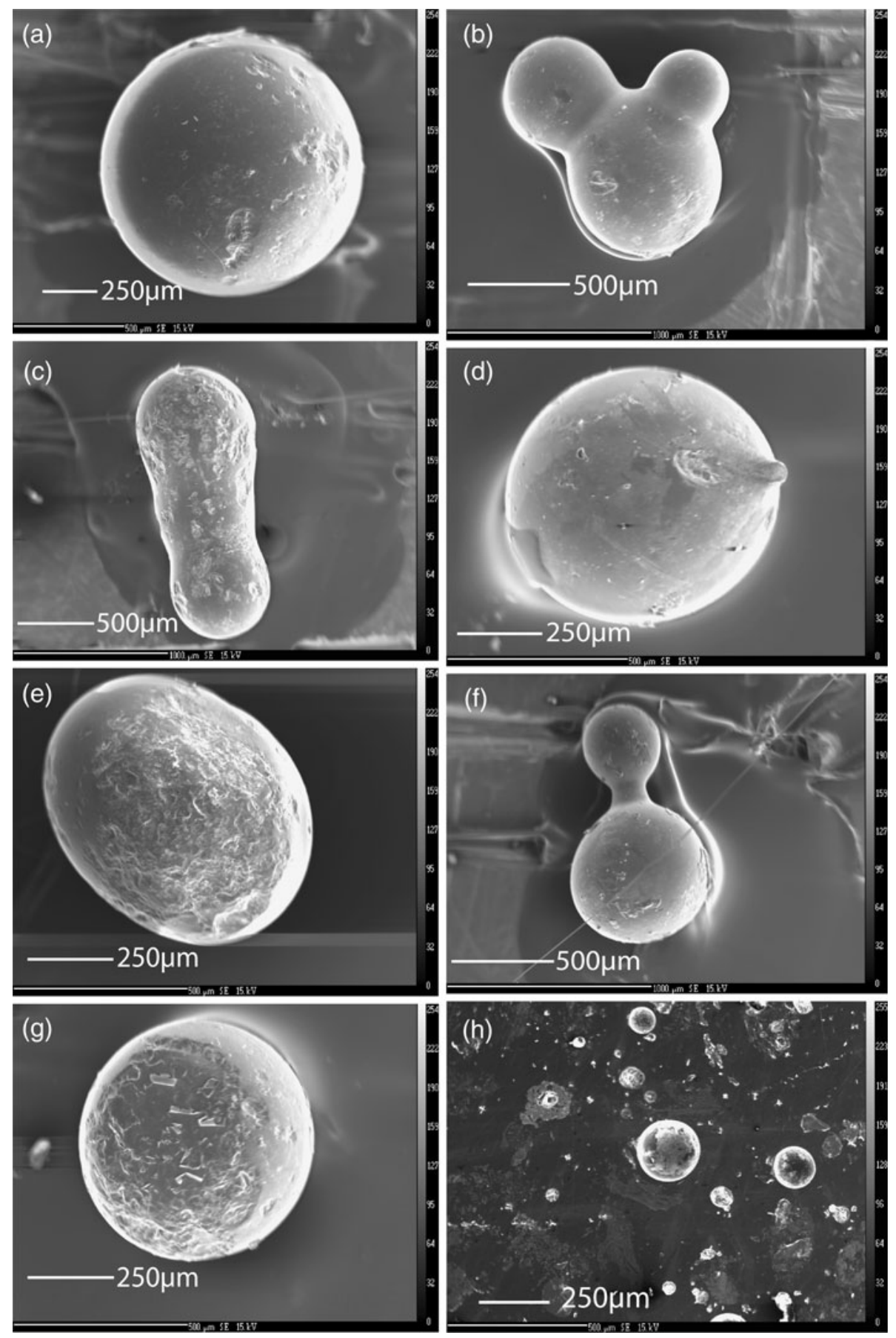

Figure 2. SEM images showing different shapes of spherules from Allahabad RDS and of fly-ash sample. (a) Spherical spherule with smooth surface and a few micropits. (b) Fused-type spherule showing two sub-spherules attached to the main one. (c) Elongated spherule with many micropits. (d) Teardrop spherule. (e) Oval spherule with numerous micropits. (f) Dumbbell spherule with a narrow neck. (g) Spherical spherule showing numerous micropits. (h) Fly ash sample from IFFCO Plant, Phulpur, Allahabad, showing many spherules.

the northern part of the city and their number decreases towards the southern part.

The $66 \%$ of all the anthropogenic spherules observed in the unsieved dust samples from Allahabad (RDS) is colourless to pale coloured (i.e., some spherules which have been noticed are light yellow coloured). The coloured anthropogenic spherules' of various hues include light grey, cream, brown and black-coloured. The metallic and dark grey spherules of the present study are predominantly observed in the Naini industrial area, Allahabad. The colourless spherules are observed both 


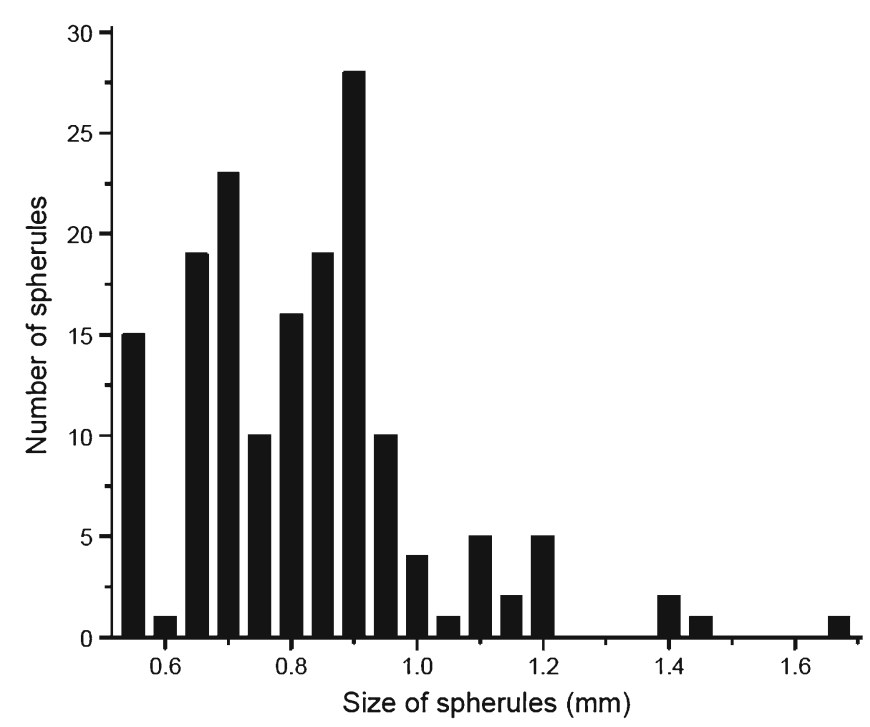

Figure 3. The size of 167 anthropogenic spherules collected from different parts of Allahabad city show a polymodal distribution with maximum numbers lying between 0.8 and $1 \mathrm{~mm}$ similar to impact spherules.

in residential as well as industrial areas of the city (table 1). The yellow coloured material present on the external surface of the spherule being analyzed is sulphur.
Compositional range of the SS is given in table 2 . The compositional ranges of morphologically similar spherules reported from Lonar impact structure (LS), Maharashtra, India (Misra et al 2009) and from microtektites (MT) in surficial sediments of the Indian Ocean (Prasad et al 2003) are given in table 2 for comparison. The $\mathrm{SiO}_{2}$ content of $\mathrm{SS}$ is between 67.96 and $85.59 \mathrm{wt} \%$ with an average value of $72.09 \mathrm{wt} \%$. MT and LS have lower $\mathrm{SiO}_{2}$ contents with average values of 68.59 and $48.31 \mathrm{wt} \%$, respectively. SS are comparatively rich in alkali component, $\mathrm{Na}_{2} \mathrm{O}(0.19-6.79 \mathrm{wt} \%)$ and $\mathrm{K}_{2} \mathrm{O}(0.26-1.04 \mathrm{wt} \%)$. The total iron content of SS expressed as $\mathrm{FeO}$ is low $(0.07-0.40) . \mathrm{Al}_{2} \mathrm{O}_{3}$ content of the SS varies between 1.21 and $3.63 \mathrm{wt} \%$ and is much lower than that of MT (10.63-21.12 wt\%) and LS (11.76-15.23 wt\%). Both $\mathrm{NiO}$ and $\mathrm{Cr}_{2} \mathrm{O}_{3}$ content are low in the case of SS (0.22 and $0.1 \mathrm{wt} \%$, respectively). In the case of $\mathrm{TiO}_{2}$, the values measure up to $0.07 \mathrm{wt} \%$. The compositional limits of the three spherule types (SS, MT and LS) are distinct as illustrated in the binary, $\mathrm{Al}_{2} \mathrm{O}_{3}$ vs. $\mathrm{SiO}_{2}$ plot (figure 4a) and ternary, $\mathrm{SiO}_{2}-(\mathrm{CaO}+\mathrm{MgO}+$ $\mathrm{FeO}^{\mathrm{T}}$ ) $-\mathrm{Al}_{2} \mathrm{O}_{3}$ plot (figure $4 \mathrm{~b}$ ) and implied origin. Surficial coating of yellow granules occurring at the neck of two attached spherules is analyzed to be

Table 2. A comparison between microtektites, impact spherules and anthropogenic spherules (present study) based on their shape, size, colour and lithophile elemental composition.

\begin{tabular}{|c|c|c|c|c|}
\hline Spherule type & Shape & Size & Colour & Chemical composition \\
\hline Microtektites & $\begin{array}{l}\text { Spherical, elongated, } \\
\text { teardrop, discs or } \\
\text { dumbbell, spindle, } \\
\text { club-shaped, } \\
\text { bun-shaped }\end{array}$ & $<1 \mathrm{~mm}$ & $\begin{array}{l}\text { Honey coloured, } \\
\text { light yellow, } \\
\text { yellowish green } \\
\text { to opaque white }\end{array}$ & $\begin{array}{l}\mathrm{SiO}_{2}: 56.26-75.74 \text { (Avg. 68.59) } \\
\mathrm{Na}_{2} \mathrm{O}: 0.41-1.04 \text { (Avg. 0.66) } \\
\mathrm{K}_{2} \mathrm{O}: 0.33-2.02 \text { (Avg. 1.00) } \\
\mathrm{Al}_{2} \mathrm{O}_{3}: 10.63-21.12 \text { (Avg. 15.33) } \\
\mathrm{MgO}: 2.38-10.62 \text { (Avg. 4.66) } \\
\mathrm{CaO}: 2.06-4.14 \text { (Avg. 3.24) } \\
\mathrm{FeO}: 3.97-9.16 \text { (Avg. 5.42) } \\
\mathrm{TiO}_{2}: 0.56-1.07 \text { (Avg. 0.84) }\end{array}$ \\
\hline Impact spherule & $\begin{array}{l}\text { Spherical, teardrop, } \\
\text { cylinder, dumbbell } \\
\text { and spindle }\end{array}$ & $\approx 0.3-1 \mathrm{~mm}$ & & $\begin{array}{l}\mathrm{SiO}_{2}: 43.33-51.39 \text { (Avg. 48.31) } \\
\mathrm{Al}_{2} \mathrm{O}_{3}: 11.76-15.23 \text { (Avg. 13.67) } \\
\mathrm{Na}_{2} \mathrm{O}: 1.23-2.38 \text { (Avg. 1.81) } \\
\mathrm{MgO}: 4.95-8.93 \text { (Avg. 6.84) } \\
\mathrm{K}_{2} \mathrm{O}: 0.19-0.78 \text { (Avg. 0.32) } \\
\mathrm{CaO}: 8.21-10.71 \text { (Avg. 9.24) } \\
\mathrm{FeO}: 11.96-16.89 \text { (Avg. 15.27) } \\
\mathrm{TiO}_{2}: 1.94-2.95 \text { (Avg. 2.32) } \\
\mathrm{P}_{2} \mathrm{O}_{5}: 0.02-0.16 \text { (Avg. 0.07) }\end{array}$ \\
\hline $\begin{array}{l}\text { Anthropogenic } \\
\text { spherule } \\
\text { (present study) }\end{array}$ & $\begin{array}{l}\text { Spherical, elliptical, } \\
\text { dumbbell, spindle, } \\
\text { teardrop and cylinder }\end{array}$ & $0.55-1.67 \mathrm{~mm}$ & $\begin{array}{l}\text { Colourless to } \\
\text { dark grey, } \\
\text { opaque white, } \\
\text { brown }\end{array}$ & $\begin{array}{l}\mathrm{SiO}_{2}: \text { 67.10-77.07(Avg. 72.09) } \\
\mathrm{Al}_{2} \mathrm{O}_{3}: 1.21-3.63 \text { (Avg. 1.70) } \\
\mathrm{Na}_{2} \mathrm{O}: 0.19-6.79 \text { (Avg. 2.31) } \\
\mathrm{MgO}: 3.62-0.30 \text { (Avg. 1.97) } \\
\mathrm{K}_{2} \mathrm{O}: 0.26-1.04 \text { (Avg. 0.50) } \\
\mathrm{CaO}: 5.01-10.16 \text { (Avg. 7.57) } \\
\mathrm{TiO}_{2}: 0.01-0.08 \text { (Avg. 0.03) } \\
\mathrm{FeO}^{*}: 0.07-0.40 \text { (Avg. 0.21) } \\
\mathrm{P}_{2} \mathrm{O}_{5}: 0.09-0.17 \text { (Avg. 0.13) }\end{array}$ \\
\hline
\end{tabular}



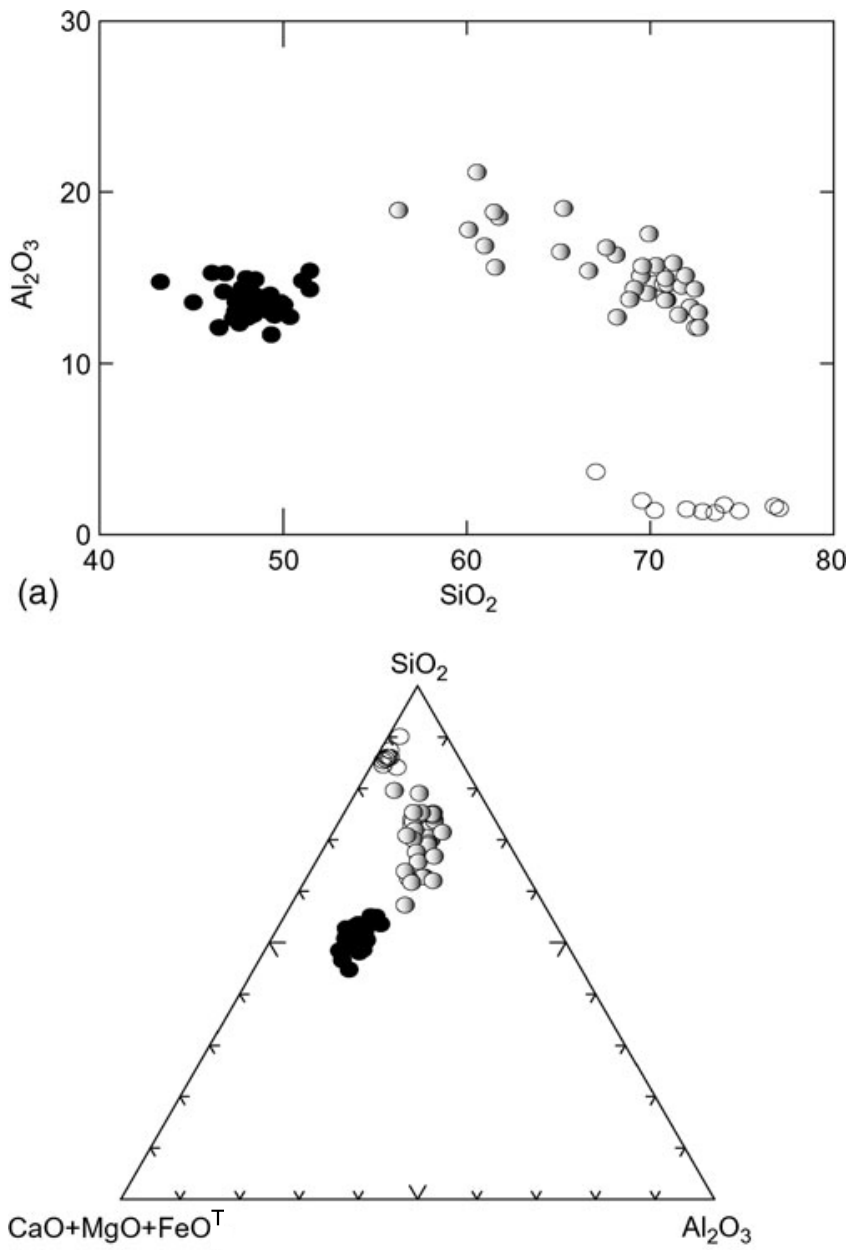

(b)

Figure 4. (a) Binary $\mathrm{Al}_{2} \mathrm{O}_{3}$ vs. $\mathrm{SiO}_{2}$ plot showing distinct domains of SS (SS; open circle) from Allahabad RDS, microtektites (MT; shaded circle) from Indian Ocean, and spherules from Lonar impact structure, Maharashtra, India (LS; solid circle). (b) Ternary $\mathrm{SiO}_{2}-(\mathrm{CaO}+$ $\left.\mathrm{MgO}+\mathrm{FeO}^{\mathrm{T}}\right)-\mathrm{Al}_{2} \mathrm{O}_{3}$ diagram showing distinction among the three spherule types. $\mathrm{FeO}^{\mathrm{T}}$ represents total iron expressed as $\mathrm{FeO}$.

sulphur. Compositional similarity between larger spherules and the smaller ones adhering to them suggests their common origin. Presence of vesicles within SS suggests the presence of a volatile phase in the system.

The BSE-SEM images and EPMA analysis of a fly-ash sample from the steam generation of the IFFCO (Indian Farmers Fertilizer Cooperative Limited) fertilizer plant at Phulpur $\left(25^{\circ} 32^{\prime} 10.64^{\prime \prime} \mathrm{N} ; 82^{\circ} 03^{\prime} 47.09^{\prime \prime} \mathrm{E}\right)$, located $40 \mathrm{~km}$ $\mathrm{NE}$ of the Allahabad city shows the presence of spherules (figure 3h) and their chemistry is similar to RDS spherules of Allahabad city, respectively.

\section{Conclusions}

The present study suggests that the shape, size, surface features and chemistry of spherules are not diagnostic of impact cratering process and cannot distinguish microtektites and impact spherules from the coal fly-ash spherules produced from natural wildfires and thermal power plants.

The various shapes (spherical and agglutinated) of SS suggest their formation at high temperature and adherence close to their respective liquidus temperature.

The composition of $\mathrm{SS}$ can be defined in ${\mathrm{a} \mathrm{SiO}_{2}-}^{-}$ $\left(\mathrm{CaO}+\mathrm{MgO}+\mathrm{FeO}^{\mathrm{T}}\right)-\mathrm{Al}_{2} \mathrm{O}_{3}$ ternary since their bulk composition in terms of the three end members lies between 80 and $90 \mathrm{wt} \%$. The microtektites are slightly better defined by the three end members (96-98 wt\%) compared to impact spherules (93-96 wt\%).

The morphology and chemistry of fly ash spherules from the coal-based thermal power plant, Phulpur, Allahabad are identical with SS observed in RDS samples suggesting their derivation from the coal-based NTPC thermal power plant situated at Phulpur.

The spatial distribution of SS indicates their transportation to different parts of Allahabad city and its adjoining areas by wind as suspended particulate matter.

The abundance of SS is high in the northern part of the Allahabad city and their numbers per location decrease southward. However, the size of the spherules observed during the present study does not show any correlation with distance.

Hence, it is necessary to adopt a multi-pronged method to evaluate the spherules before assigning their origin as they can be carried over hundreds of $\mathrm{km}$ in air from various sources prior to their deposition.

\section{Acknowledgements}

Dr Martin Schmieder, University of Stuttgart, Germany is immensely thanked for his excellent presubmission review of the manuscript. JKP thanks the PLANEX Programme, Physical Research Laboratory (Department of Space), Ahmedabad for analytical support and field equipments. The DST, New Delhi is thanked for providing a research microscope used in the present study through grant no. ESS/16/195/2003. AN thanks the University of Allahabad for CRET Scholarship and this work forms part of her D.Phil. thesis. Some of the samples used in the present study are collected during Mr. R K Gautam's M.Sc. dissertation project. An anonymous reviewer and Dr Rajat Mazumder are thanked for their comments and editorial handling, respectively. 


\section{References}

Bhanarkar A D, Gavane A G, Tajne D S, Tamhane S M and Nema P 2008 Composition and size distribution of particules emissions from a coal-fired power plant in India; Fuel 87 2095-2101.

Blaha U, Sapkota B, Appel E, Stanjek H and Rösler W 2008 Micro-scale grain analysis and magnetic properties of coal-fired power plant fly ash and its relevance for environmental magnetic pollution studies; Atmos. Environ. $428359-8370$.

Bohor B F 1990 Shock-induced microdeformations in quartz and other mineralogical indications of an impact event at the Cretaceous-Tertiary boundary; Tectonophys. 171 359-372.

Buchner E, Schmieder M, Strasser M, Strasser A and Krochert J 2009 Impacts on Spherules; 40th Lunar and Planetary Science Conference.

Dayal U and Sinha R 2005 Geoenvironmental Design Practice in Flyash Disposal and Utilization; Allied Publishers, New Delhi.

Fredriksson K 1956 Cosmic spherules in deep-sea sediments; Nature 177 32-33.

French B M and Koeberl C 2010 The convincing identification of terrestrial meteorite impact structures: What works, what doesn't, and why; Earth Sci. Rev. 98 $123-170$

Gautam P, Blaha U and Appel E 2005 Magnetic susceptibility of dust-loaded leaves as a proxy of traffic-related heavy metal pollution in Kathmandu city, Nepal; Atmos. Environ. 39 2201-2211.

Glass B P and Wu J 1993 Coesite and shocked quartz discovered in the Australasian and North American microtektite layers; Geology 21 435-438.

Glikson A Y 2005 Geochemical signatures of Archean to Early Proterozoic Maria-scale oceanic impact basins; Geology 33 125-128.

Goddu S R, Appel E, Jordanova D and Wehland F 2004 Magnetic properties of road dust from Visakhapatnam (India) - relationship to industrial pollution and road traffic; Physics and Chemistry of the Earth 29 985-995.

Grasby S E, Sanei H and Beauchamp B 2011 Catastrophic dispersion of coal fly ash into oceans during the latest Permian extinction; Nature Geoscience, doi: 10.1038/NGEO10691-4.

Hofmann A, Reimold W U and Koeberl C 2006 Archean spherule layers in the Barberton Greenstone Belt, South Africa: A discussion of problems related to the impact interpretation; Geo. Soc. Am. Spec. Paper 405, http://elements.geoscienceworld.org/content/vol6/issue4/ \#ARTICLES (accessed on 15:04:2011).

Jordanova D, Jordanova N and Hoffmann V 2006 Magnetic mineralogy and grain-size dependence of hysteresis parameters of single spherules from industrial waste products; Phys. Earth Planet. Interiors 154 255-265.

Kim W, Doh S J and Yu Y 2009 Anthropogenic contribution of magnetic particulates in urban roadside dust; Atmos. Environ. 43 3137-3144.

Kofman R S, Herd C D K and Froese D G 2010 The Whitecourt meteorite impact crater, Alberta, Canada; Meteor. Planet. Sci. 45 1429-1445.

Kyte F T, Shukolyukov A, Lugmair G W, Lowe D R and Byerly G R 2003 Early Archean spherule beds: Chromium isotopes confirm origin through multiple impacts of projectiles of carbonaceous chondrite type; Geology 31 283-286.

Lowe D R, Byerly G R, Asaro F and Kyte F T 1989 Geological and geochemical record of 3400-million-year-old terrestrial meteorite impacts; Science 245 959-962.
Margolis S V, Barnes V, Cloud P and Fisher R V 1971 Surface micrography of lunar fines compared with tektites and terrestrial volcanic analogs; Proc. 2nd $L P S C \mathbf{1}$ 909-921.

Marini F 2003 Natural microtektites versus industrial glass beads: An appraisal of contamination problem; J. NonCrystalline Solids 323 104-110.

Misra S, Newsom H E, Prasad M S, Geissman J W, Dube A and Sengupta D 2009 Geochemical identification of impactor for Lonar crater, India; Meteor. Planet. Sci. 44 1001-1018.

Montanari A and Koeberl C 2000 Impact Stratigraphy. The Italian Record; Geol. Mag. 2001138 503-504.

Osawa T, Nagao K, Noguchi T, Nakazawa A and Mikada J 2003 Remnant extraterrestrial noble gases in Antarctic cosmic spherules; Antarctic Meteorite Research $\mathbf{1 6}$ 196-219.

Pattan J N, Prasad M S and Babu E V S S K 2010 Correlation of the oldest Toba Tuff to sediments in the central Indian Ocean Basin; J. Earth Syst. Sci. 119 531-539.

Prasad M S and Sudhakar M 1996 Microimpact phenomena on Australasian microtektites: Implications for ejecta plume characteristics and lunar surface; Meteor. Planet. Sci. 33 1271-1279.

Prasad M S and Sudhakar M 1998 Australasian microtektites from the Central Indian Basin: Implications for ejecta distribution patterns; Curr. Sci. 70 74-77.

Prasad M S, Gupta S M and Kodagali V N 2003 Two layers of Australasian impact ejecta in the Indian Ocean; Meteor. Planet. Sci. 38 1373-1381.

Raukas A 2000 Investigation of impact spherules - a new promising method for the correlation of Quaternary deposits; Quat. Int. 68-71 241-252.

Reimold W U, Trepmann C and Simonson B 2006 Discussion - Impact origin of the Ramgarh structure, Rajasthan: Some new evidences (eds) Sisodia et al; J. Geol. Soc. India 68 561-563.

Saragnese F, Lanci L and Lanza R 2010 Nanometric-sized atmospheric particulate studied by magnetic analyses; Atmos. Environ. XXX 1-10.

Sarkara A, Rano R, Mishra K K and Sinha I N 2005 Particle size distribution profile of some Indian fly ash - a comparative study to assess their possible uses; Fuel Processing Technology 86 1221-1238.

Scally A and Simonson B M 2005 Spherule textures in the Neoarchean Wittenoom impact layer, Western Australia: consistency in diversity; Aust. J. Earth Sci. 52 $773-783$.

Schulte P, Alegret L, Arenillas I, Arz J A, Barton P J, Bown P R, Bralower T J, Christeson G L, Claeys P, Cockell C S, Collins G S, Deutsch A, Goldin T J, Goto K, GrajalesNishimura J M, Grieve R A F, Gulick S P S, Johnson K R, Kiessling W, Koeberl C, Kring D A, MacLeod K G, Matsui T, Melosh J, Montanari A, Morgan J V, Neal C R, Nichols D J, Norris R D, Pierazzo E, Ravizza G, Rebolledo-Vieyra M, Reimold W U, Robin E, Salge T, Speijer R P, Sweet A R, Urrutia-Fucugauchi J, Vajda V, Whalen M T and Willumsen P S 2010 The Chicxulub Asteroid Impact and Mass Extinction at the CretaceousPaleogene Boundary; Science 137 1214-1218.

Sharma R, Pervez Y and Pervez S 2005 Seasonal evaluation and spatial variability of suspended particulate matter in the vicinity of a large coal-fired power station in India A case study; Environmental Monitoring and Assessment $1021-13$

Simonson B M 2003 Petrographic criteria for recognizing certain types of impact spherules in well-preserved Precambrian successions; Rubey Colloquim paper; Astrobiology 3(1) 49-65. 
Simonson B M, Davies D and Hassler S W 2000 Discovery of a layer of probable impact melt spherules in the late Archean Jeerinah Formation (Fortescue Group, Western Australia); Aust. J. Earth Sci. 47 315-325.

Simonson B M, McDonald I, Shukolyukov A, Koeberl C, Reimold W U and Lugmair G W 2009 Geochemistry of 2.63-2.49 Ga impact spherule layers and implications for stratigraphic correlations and impact processes; Precamb. Res. 175 51-76.

Sisodia M S, Lashkari G and Bhandari N 2006 Impact origin of the Ramgarh structure, Rajasthan: Some new evidences; J. Geol. Soc. India 67 423-431.

Smit J, Alvarez W, Montanari A, Swinburne N, Van Kempen T N, Klaver G T and Lustenhouwer W J 1992 Tektites and microkrystites at the Cretaceous Tertiary boundary: Two strewn fields, one crater? In: Proceedings of the 22nd Lunar and Planetary Science Conference, Lunar and Planetary Institute, Houston, pp. 87-100.

Sweeney D and Simonson B M 2008 Textural constraints on the formation of impact spherules: A case study from the Dales Gorge BIF, Paleoproterozoic Hamersley Group of Western Australia; Meteor. Planet. Sci. 43 2073-2087.
Thorpe A and Harrison R M 2008 Source and properties of non-exhaust particulate matter from road traffic: A review; Sci. Total Environ. 400 270-282.

Walkden G, Parker J and Kelley S 2002 A Late Triassic impact ejecta layer in southwestern Britain; Science $\mathbf{2 9 8}$ 2185-2188.

Weiss B P, Pedersen S, Garrick-Bethell I, Stewert S T, Louzada K L, Maloof A C and Swason-Hysell N L 2010 Paleomagnetism of impact spherules from Lonar crater, India and a test for impact-generated fields; Earth Planet. Sci. Lett. 298 66-76.

Whitehead J, Papanastassiou D A, Spray J G, Grieve R A F and Wasserburg G J 2000 Late Eocene impact ejecta: Geochemical and isotopic connections with the Popigai impact structure; Earth Planet. Sci. Lett. 181(4) 473-487.

Xie R K, Seip H M, Liu L and Zhang D S 2009 Characterization of individual airborne particles in Taiyuan City, China; Air Qual. Atmos. Health 2 123-131.

Yang T, Liu Q, Li H, Zeng Q and Chan L 2010 Anthropogenic magnetic particles and heavy metals in the road dust: Magnetic identification and its implications; Atmos. Environ. 44 1175-1185. 